\title{
Moisture and Bio-Deterioration Risk of Building Materials and Structures
}

\author{
Hannu Viitanen \\ VTT \\ Finland
}

\section{Introduction}

During the service life of buildings, natural aging and eventual damage of materials due to different chemical, physical, and biological processes can take place. Ageing of the materials is one aspect of the environmental processes and involve different chemical, mechanical and biological reactions of the materials. Bio-deterioration, e.g. mould, decay and insect damage in buildings, is caused when moisture exceeds the tolerance of structures which may be a critical factor for durability and usage of different building materials.

Modelling of the development of mould growth and decay development is a tool for evaluate the eventual risk of ambient humidity or moisture conditions of materials for biodeterioration of materials. The modelling can be used in combination of hygro-thermal analyses of building and building components.

Moisture availability is the primary factor controlling mould growth and decay development, but the characteristics of the substrate and environmental conditions determine the dynamics of the growth. However, moist materials may also dry and become wet again thus, resulting in fluctuating moisture conditions. Mould and decay problems in buildings are most often caused by moisture damage: water leakage, convection of damp air and moisture condensation, rising damp from the ground and moisture accumulation in the structure. Repeated or prolonged moisture penetration into the structure is needed for damage to develop.

\section{Critical environmental conditions for bio-deterioration}

There are several biological processes causing aging and damage to buildings and building components. This is due to natural ageing of materials but also caused by excessive moisture and damage of materials. For mould development, the minimum (critical) ambient humidity requirement is shown to be between $\mathrm{RH} 80$ and $95 \%$ depending on other factors like ambient temperature, exposure time, and the type and surface conditions of building materials (Table 1) For decay development, the critical humidity is above RH $95 \%$. Mould typically affects the quality of the surfaces and the adjacent air space with volatile compounds and spores. The next stage of moisture induced damage, the decay development, forms a serious risk for structural strength depending on moisture content, materials, temperature and time. The worst decay damage cases in North Europe are found in the floors and lower parts of walls, where water accumulates due to different reasons. 


\begin{tabular}{|c|c|c|c|}
\hline $\begin{array}{l}\text { Type of } \\
\text { organism }\end{array}$ & Damage / problem type & $\begin{array}{l}\text { Humidity or moisture range } \\
\text { (RH or MC \%) }\end{array}$ & $\begin{array}{l}\text { Temperature } \\
\text { range }\left({ }^{\circ} \mathrm{C}\right)\end{array}$ \\
\hline bacteria & $\begin{array}{l}\text { bio corrosion of many } \\
\text { different materials, smell, } \\
\text { health problems }\end{array}$ & $\begin{array}{l}\text { wet materials } \\
\mathrm{RH}>97 \%\end{array}$ & ca. -5 to +60 \\
\hline mould fungi & $\begin{array}{l}\text { surface growth on } \\
\text { different materials, } \\
\text { smell and health problems }\end{array}$ & $\begin{array}{l}\text { Ambient } \mathrm{RH}>75 \% \text {, } \\
\text { depends on duration, } \\
\text { temperature and mould species }\end{array}$ & ca. 0 to +50 \\
\hline $\begin{array}{l}\text { blue-stain } \\
\text { fungi }\end{array}$ & $\begin{array}{l}\text { blue-stain of wood } \\
\text { permeability } \\
\text { change of wood }\end{array}$ & $\begin{array}{l}\text { Wood moisture content }>25 \text { - } \\
120 \% \\
\text { RH }>95 \%\end{array}$ & ca. -5 to +45 \\
\hline decay fungi & $\begin{array}{l}\text { different types of decay in } \\
\text { wood (soft rot, brown rot } \\
\text { or white rot), also many } \\
\text { other materials can be } \\
\text { deteriorated, } \\
\text { Strength loss of materials. }\end{array}$ & $\begin{array}{l}\text { Ambient RH }>95 \% \text {, } \\
\text { MC }>25-120 \% \text {, depends on } \\
\text { duration, temperature, fungus } \\
\text { species and materials }\end{array}$ & ca. 0 to +45 \\
\hline $\begin{array}{l}\text { algae and } \\
\text { lichen }\end{array}$ & $\begin{array}{l}\text { Surface growth of different } \\
\text { materials on outside or } \\
\text { weathered material. }\end{array}$ & $\begin{array}{l}\text { wet materials } \\
\text { also nitrogen and } \\
\text { low pH are needed }\end{array}$ & ca. 0 to +45 \\
\hline insects & $\begin{array}{l}\text { Different type of damage } \\
\text { in organic materials, } \\
\text { surface failures or } \\
\text { strength loss. }\end{array}$ & $\begin{array}{l}\text { Ambient } \mathrm{RH}>65 \% \\
\text { depends on duration, } \\
\text { temperature, species and } \\
\text { environment }\end{array}$ & ca. 5 to +50 \\
\hline
\end{tabular}

Table 1. Organisms involving damages and defects of building components (Viitanen and Salonvaara 2001, Viitanen et al. 2003)

In Northern Europe, the roofs, floors and lower parts of walls are most often exposed to high humidity and potential attack by biodeterioration processes (Paajanen and Viitanen 1989, Viitanen 2001a, Kääriäinen et al. 1998) when also decay will develop. For the decay development, the humidity and moisture conditions will be higher than that for mould growth, and modelling of decay risk is a separate task. Mould growth is often typical in materials in exterior conditions. In damage conditions, however, different decay types can be found: brown rot, soft rot, and white rot. In buildings suffering from excessive moisture loading, brown rot is the most common decay type (Paajanen and Viitanen 1989, Viitanen 2001a).

The other a-biotic factors like UV radiation and quality of substrate (nutrients, $\mathrm{pH}$, hygroscopicity, water permeability) are also significant for the growth of organisms. Different organisms, e.g. bacteria, fungi and insects, can grow and live in the building materials; microbiologically clean buildings probably do not exist, as some contamination begins as early as during the construction phase. The humidity / moisture conditions connected with temperature and exposure time are the most important factor for development of biological problems and damage in buildings.

The research and modelling of mould growth is most often performed under constant conditions when the ambient humidity conditions and microclimate will prevail for longer periods. Ayerst (1969) and Smith and Hill (1982) studied the effect of temperature and water 
activity on germination and growth of selected mould fungi. They developed isopleths for the growth conditions of mould fungi on agar media. An isopleths is a boundary that defines all combinations of temperature and relative humidity that permit a particular mould growth rate. Grant et al. (1989) analysed and modelled the moisture requirements of some mould fungi isolated from dwellings. A certain succession, depending on the moisture requirements of different fungal species: primary, secondary and tertiary colonizers, was found.

Research with building materials will be better fitted to the moisture problems in buildings. Adan (1994) used a non-linear regression technique to model sigmoid curves describing vegetative fungal growth of Penicillium chrysogenum on gypsum board material. He used the time-of-wetness (TOW) as an overall measure of water availability for fungal growth under fluctuating humidity conditions. The TOW is defined by the ratio of the cyclic wet period $(\mathrm{RH} \geq 80 \%)$ and the cyclic dry period. The mould growth is a function of the effect of lowest humidity, time of wetness and high relative humidity frequency, and finally of periods of wet and dry conditions. He used Low Temperature Scanning Electronic Microscope LTSEM to analyse the growth and studied the effect of coatings and surface quality on the mould growth. He also evaluated the effect of distribution of growth density on test results. Clarke et al. (1998) developed a simulation model and tool for mould growth prediction in buildings based on an analysis of published data using growth limit curves for six generic mould categories. These limits have been incorporated within the ESP-r (building Energy Software) system for use in conjunction within combined heat and moisture flow simulation.

\section{Modeling of development of mould growth}

\subsection{Mould growth on building materials}

Modelling of mould growth and decay development based on humidity, temperature, exposure time and material will give tools for the evaluation of durability of different building materials and structures. The models make it possible to evaluate the risk and development of mould growth and to analyse the critical conditions needed for the start of growth of microbes and fungi. The model is also a tool to simulate the progress of mould and decay development under different conditions on the structure surfaces. This requires that the moisture capacity and moisture transport properties in the material and at the surface layer have been taken into account in the simulations. In practice there are even more parameters affecting mould growth, e.g. thickness of the material layers combined with the local surface heat and mass transfer coefficients. Therefore, the outcome of the simulations and in-situ observations of biological deterioration may not agree. One of the results of a newly finished large Finnish research project "Modelling of mould growth" is an improved and extended mathematical model for mould growth based on development of mould index in different materials under different exposure conditions (table 2).

Hukka and Viitanen (1999) and Viitanen et al. (2000) presented a model of mould growth which is based on duration of suitable exposure conditions required before microbial growth will start or the damage will reach a certain degree. Particular emphasis is focused on this time period, the so-called response time or response duration, in different humidity and temperature conditions for the start of mould growth (Figure 1). The model is based on the large laboratory studies on Scots pine and Norway spruce sapwood. 


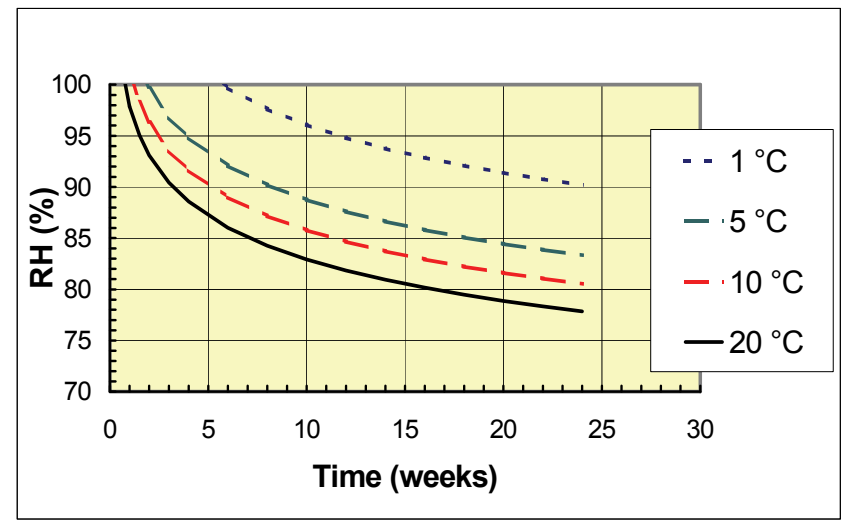

Fig. 1. Critical humidity (RH \%), time (weeks) and temperature needed to start mould growth on pine sapwood (Viitanen 1996)

The growth of mould in this model was evaluated using the "mould index" scale shown in Table 2. The model can be used to evaluate the mould growth in different exposure conditions, and it can be introduced to building physic modeling to evaluate the performance of different structure. The model is not suitable for evaluate the development of decay, for which different models exist (Viitanen 1996, Viitanen et al. 2000).

The model describes also the dynamic nature of mould growth under varying temperature and humidity conditions as it gives the predicted mould index as a function of time. Simulation results with the model show that under fluctuating humidity, the mould index will decrease during low humidity or temperature periods, depending on the time periods (Figure 2). This kind of behaviour can also be found in the "Modelling of mould growth" study (Viitanen et al 2010).
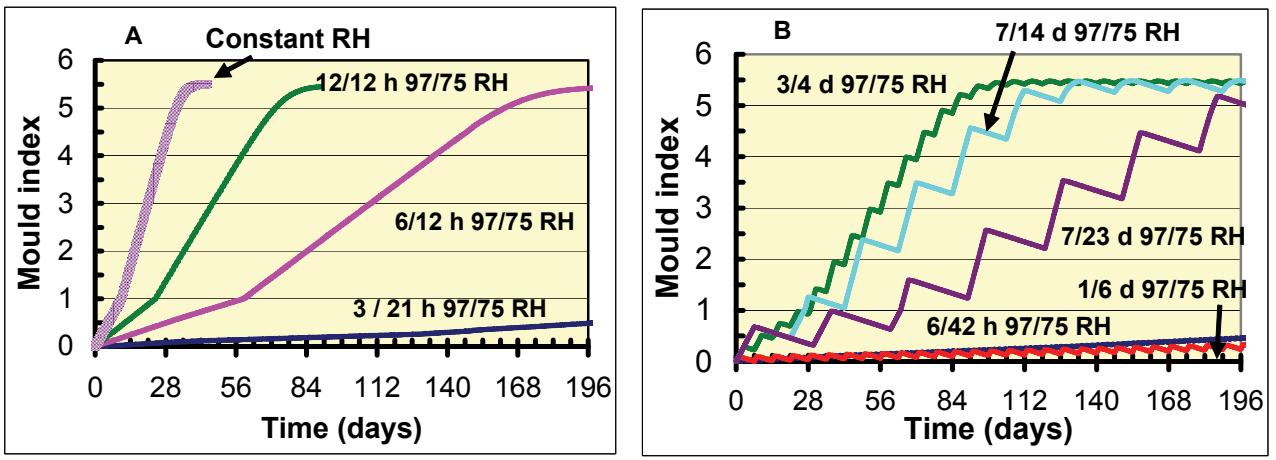

Fig. 2. Modelling the effect of varied fluctuating humidity conditions on the development of mould index in pine sapwood (Viitanen et al. 2000)

The original index is based on wood materials (Viitanen and Ritschkoff 1991a). New determinations for index levels 3 and 4 for other materials are presented using bold fonts and has been presented by Viitanen et al (2011a). 


\begin{tabular}{cc}
\hline Index & Description of the growth rate \\
\hline \hline 0 & No growth \\
1 & Small amounts of mould on surface (microscope), initial stages of \\
local growth
\end{tabular}

Table 2. Mould index for experiments and modeling of mould growth on building materials

Sedlbauer (2001) studied different models to evaluate spore germination and growth of different mould species on different types of materials. He found, that the isopleths developed by growth of mould on an artificial medium can be used to evaluate the growth rate of different fungi. He used a hygrothermal model based on the relative humidity, temperature and exposure time needed for the spore germination of mould fungi based on the osmotic potential of spores. He analysed the effect of different climatic conditions on the spore moisture content and germination. He also evaluated the spore moisture content and germination time based on calculated time courses of temperature and relative humidity in various positions of the exterior plaster of an external wall using WUFI program (Sedbauer and Krus 2003). In Figure 3, a comparison of the critical conditions for mould growth assumed by some of mould growth models is shown. These curves represent lower limiting isopleths (humidity levels) for mould growth.

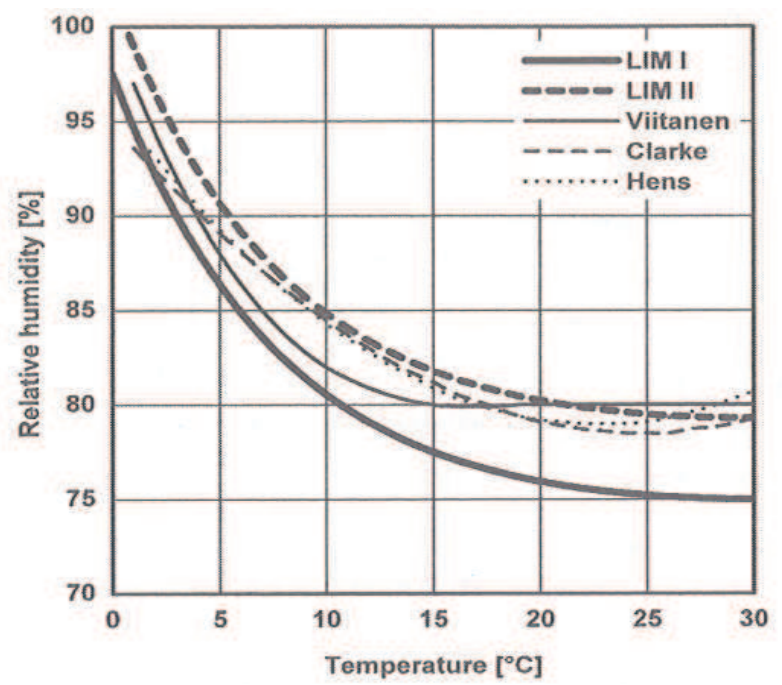

Fig. 3. Comparison of the LIM's of substrate class 1 (LIM I, biodegradable materials) and substrate class 2 (LIM II, porous materials) after Sedlbauer (2001) with data from results of building materials after Viitanen et al. (2000), Clarke et al. (1998) and Hens (1999) 
The first version of the mould growth model was based on large laboratory studies with pine sapwood (Viitanen and Ritschkoff 1989). The mould growth intensities were determined at the constant conditions. In the later stages, studies in varied and fluctuated humidity conditions were performed and based on these studies, mould growth model (equation 1) was presented by Hukka and Viitanen 1999.

$$
\frac{d M}{d t}=\frac{1}{7 \cdot \exp (-0.68 \ln T-13.9 \ln R H+0.14 W-0.33 S Q+66.02)} k_{1} k_{2}
$$

where the factor $k_{1}$ represents the intensity of growth (Equation 3$), \mathrm{W}$ is the timber species $(0$ $=$ pine and $1=$ spruce) and $S Q$ is the term for surface quality $(\mathrm{SQ}=0$ for sawn surface, $\mathrm{SQ}=$ 1 for kiln dried quality) based on Hukka and Viitanen (1999).

For other materials than wood the value $\mathrm{SQ}=0$ is used, which omits this factor. Numerical simulation is typically carried out using one hour time steps (climate data intervals) and hours are used in the equations instead of days.

$$
k_{1}=\left\{\begin{array}{lc}
1 & \text { when } M \leq 1 \\
\frac{2}{t_{M=3} / t_{M=1}-1} & \text { when } M>1
\end{array}\right.
$$

In the equation, the factor $t_{M=1}$ is the time needed to start of the growth $(M=1$, Table 2$)$, and $t_{M=3}$ the time needed to reach the level $M=3$. The factor $k_{2}$ (Equation 3) represents the moderation of the growth intensity when the mould index (M) level approaches the maximum peak value in the range of $4<\mathrm{M}<6$.

$$
k_{2}=\max \left[1-\exp \left[2.3 \cdot\left(M-M_{\max }\right)\right], 0\right]
$$

where the maximum mould index $\mathrm{M}_{\max }$ level depends on the current conditions (Equation 4):

$$
M_{\max }=1+7 \cdot \frac{R H_{c r i t}-R H}{R H_{c r i t}-100}-2 \cdot\left(\frac{R H_{c r i t}-R H}{R H_{c r i t}-100}\right)^{2}
$$

In Equation $4 \mathrm{RH}_{\text {crit }}$ is the limit $\mathrm{RH}$ level to start the mould growth (Viitanen et al 2011a).

For other materials than wood, the model has to be modified. The new mould growth intensity factors are presented as relative values compared to those of the reference material pine by using Equations (5) and (6).

$$
\begin{gathered}
k_{1}=\frac{t_{M=1, \text { pine }}}{t_{M=1}} \text { when } M<1 \\
k_{1}=2 \cdot \frac{\left(t_{M=3, \text { pine }}-t_{M=1, \text { pine }}\right)}{t_{M=3}-t_{M=1}} \text { when } M \geq 1
\end{gathered}
$$

where $t_{M=1}$ is the time needed for the material to start the growth (Mould index reaches level $M=1$ ), and $t_{M=3}$ the time needed for the material to reach level $M=3$. The subscript pine refers to the value with the reference material pine. 
The mould growth maximum values set restrictions for the growth and limit the index to realistic levels. For the new set of materials the equation of the maximum mould index level was written in form shown in equation 7 (Ojanen et al 2010, Viitanen et al 2011a):

$$
M_{\max }=A+B \cdot \frac{R H_{\text {crit }}-R H}{R H_{\text {crit }}-100}-C \cdot\left(\frac{R H_{\text {crit }}-R H}{R H_{\text {crit }}-100}\right)^{2}
$$

In this equation the coefficients $\mathrm{A}, \mathrm{B}$ and $\mathrm{C}$ can have values that depend on the material class. The new $M_{\max }$ has an effect on the factor $k_{2}$ (Equation 3) and it contributes to the simulation results. Table 4 presents the maximum levels of mould index values for different materials under different conditions. These results were classified to material sensitivity groups, presented both for growth intensities and maximum mould index levels. Table 3 gives the values for the growth intensity parameter $k_{1}$ classes and for the coefficients of the maximum mould index factors $\mathrm{M}_{\max }$ and $\mathrm{k}_{2}$. The factor $\mathrm{RH}_{\min }$ represents the minimum humidity level for starting mould growth for each material group.

\begin{tabular}{|c|c|c|c|c|c|c|}
\hline \multirow[b]{2}{*}{ Sensitivity class } & \multicolumn{2}{|c|}{$\mathbf{k}_{1}$} & \multicolumn{3}{|c|}{$\mathbf{k}_{2}\left(M_{\max }\right)$} & \multirow{2}{*}{$\begin{array}{c}\mathbf{R H}_{\min } \\
\%\end{array}$} \\
\hline & $M<1$ & $M \geq 1$ & A & B & $\mathrm{C}$ & \\
\hline very sensitive, vs & 1 & 2 & 1 & 7 & 2 & 80 \\
\hline sensitive, $\mathrm{s}$ & 0.578 & 0.386 & 0.3 & 6 & 1 & 80 \\
\hline medium resistant, $\mathrm{mr}$ & 0.072 & 0.097 & 0 & 5 & 1.5 & 85 \\
\hline resistant, $\mathrm{r}$ & 0.033 & 0.014 & 0 & 3 & 1 & 85 \\
\hline
\end{tabular}

Table 3. Parameters for the sensitivity classes of the updated mould model (Ojanen et al 2010, Viitanen et al 2011a)

\begin{tabular}{|c|c|c|}
\hline Sensitivity & Materials & \\
\hline $\begin{array}{c}\text { Very } \\
\text { sensitive }\end{array}$ & Pine sapwood & very sensitive \\
\hline Sensitive & $\begin{array}{l}\text { Glued wooden } \\
\text { boards, PUR (paper } \\
\text { surface), spruce }\end{array}$ & $\begin{array}{l}\text { medium resistant } \\
\text { resistant }\end{array}$ \\
\hline $\begin{array}{l}\text { Medium } \\
\text { resistant }\end{array}$ & $\begin{array}{c}\text { Concrete, aerated } \\
\text { and cellular } \\
\text { concrete, glass wool, } \\
\text { polyester wool }\end{array}$ & 2 \\
\hline Resistant & $\begin{array}{l}\text { PUR polished } \\
\text { surface }\end{array}$ & 0 순 \\
\hline
\end{tabular}

Table 4. Mould growth sensitivity classes and some corresponding materials in the research. The figure in table illustrates the predicted mould growth for the established sensitivity classes for constant conditions at $97 \%$ RH and 22 C (Viitanen et al 2011) 
The factors presented in Table 3 form the new basis for numerical simulation of mould growth on different material surfaces. These values will be applied in the following studies where the model performance will be evaluated.

Table 4 represents the tested materials, whose resulting mould indexes were used for the determination of $\mathrm{k}_{1}$ for the respective classes. The $\mathrm{k}_{1}$ classes were determined by using expert estimation for most suitable values.

\subsection{Decline of the mould growth and mould index caused by frost or dry condition}

As living organisms mould fungi need water and suitable temperature to grow. When conditions are unfavourable for fungi, activity of mould fungi will be inactivated depending on the extent of the frost or dryness and the time periods of unfavourable conditions. In Figure 4, the humidity and temperature conditions of microclimate for the favourable and unfavourable conditions for mould growth is shown. The rate of humidity and temperature and the time periods in favourable and unfavourable conditions will affect on the growth rate of mould. Especially the longer periods in low humidity or temperature will cause decline of the mould growth and development and even the decline of mould index.

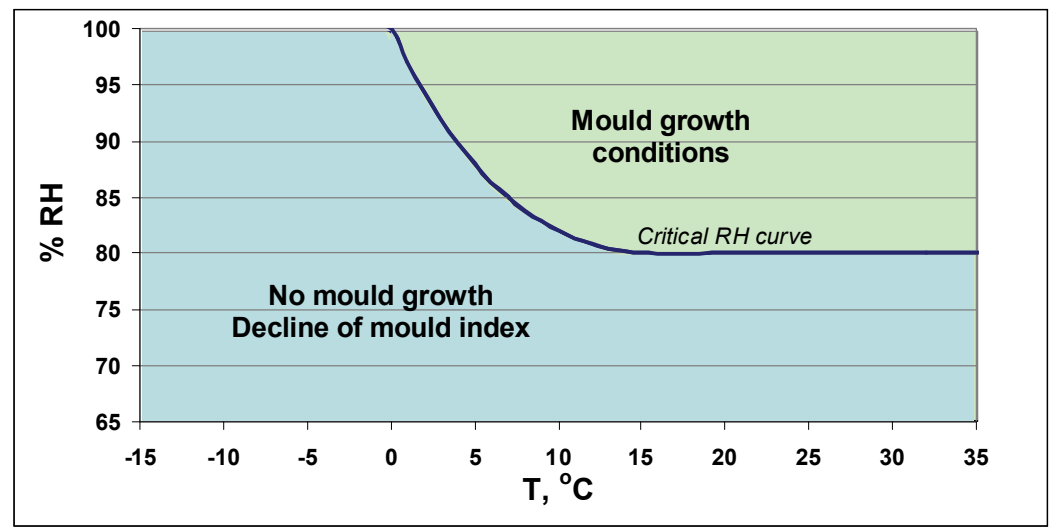

Fig. 4. Illustration of the regimes for the favourable and unfavourable conditions for mould growth (Viitanen et al 2011a)

The decline of mould growth on wooden surface has been modelled based on cyclic changes between two humidity conditions (Equation 8). The decline of mould index under different fluctuating conditions is modelled and shown in the figure 2.

$$
\frac{d M}{d t}=\left\{\begin{array}{l}
-0.00133, \text { when } t-t_{1} \leq 6 \mathrm{~h} \\
0, \text { when } 6 \mathrm{~h} \leq t-t_{1} \leq 24 \mathrm{~h} \\
-0.000667, \text { when } t-t_{1}>24 \mathrm{~h}
\end{array}\right.
$$

where $\mathrm{M}$ is the mould index and $\mathrm{t}$ is the time (h) from the moment $t_{1}$ when the conditions on the critical surface changed from growth to outside growth conditions (Hukka and Viitanen 1999).

Under long period seasonal variations of humidity conditions the decline of mould index may differ from that presented in Equation 8. Also the material may have a significant effect 
on the decline process. The decline of mould index for other materials was presented using a constant, relative coefficient for each material (Equation 9).

$$
{\frac{d M}{d t_{\text {mat }}}}^{=} C_{\text {mat }} \cdot \frac{d M}{d t_{0}}
$$

where $(\mathrm{dM} / \mathrm{dt})_{\text {mat }}$ is the mould decline intensity for each material, $(\mathrm{dM} / \mathrm{dt})_{0}$ is that for pine in the original model (Equation 9), and $C_{\text {mat }}$ is the relative coefficient for mould index decline used in the simulation model. The original decline model for wood could be applied using these additional factors (Ojanen et al 2010, Viitanen et al 2011a).

The relative decline of mould for different materials was determined using laboratory experiments with walls (Ojanen et al 2010). The temperature and relative humidity conditions on the critical boundary layer between two different materials were monitored continuously. The mould index level of the material surfaces was determined with suitable intervals by opening the structure from three different parts. The experimental target conditions at the interface of the two materials are presented in Table 5.

These experimental walls had mould growth after the first warm and humid period ('Summer/autumn'). The mould decline was determined by the change of the mould index during the second period, a four month long 'Winter' period causing freezing temperatures at the critical boundary. The mould index values were determined for both material surfaces on each critical interface. Figure 11 presents the relative mould decline values $\left(C_{\text {mat }}\right)$ solved from the observations in the experiments. The results include the detected mean, minimum and maximum mould index values.

\begin{tabular}{ccccc}
\hline Stage & $\mathbf{1}$ & $\mathbf{2}$ & $\mathbf{3}$ & $\mathbf{4}$ \\
Season & Summer/autumn & Winter & Spring & High exposure \\
Time, months & 7 & 4 & 6 & 12 \\
RH \% & $80 \ldots 100$ & $92 \ldots 100$ & $60 \ldots 95$ & $94 \ldots 100$ \\
Temperature ${ }^{\circ} \mathrm{C}$ & $27 \ldots 18$ & $-5 \ldots+3$ & $2 \ldots 10$ & $20 \ldots 24$ \\
\hline
\end{tabular}

Table 5. Exposure conditions during the wall assemble test (Ojanen et al 2010)

The decline of mould intensity on different materials under unfavourable mould growth conditions could be presented as decline classes (Table 6). This classification is based on few measurements with relatively large scattering and it should be considered as the first approximation of these classes. It was found, that the decline was larger within wood

\begin{tabular}{|c|c|}
\hline $\mathbf{C}_{\text {eff }}$ & Description \\
\hline 1.0 & Pine in original model, short periods \\
\hline 0.5 & Significant Relevant decline \\
\hline 0.25 & Relatively low decline \\
\hline 0.1 & Almost no decline \\
\hline
\end{tabular}

Table 6. Classification of relative mould index decline (Ojanen et al 2010) 


\section{Modeling of development of decay}

\subsection{Causes for decay damages in buildings}

The excessive water into the building structure and materials is the basic cause to different bio-deterioration problems like decay. For instance, in washrooms water often penetrates through inside surfaces or pipe leakage into the structures causing long lasting high humidity conditions. In old wooden buildings, the floor has often been built above a cold ventilated basement or crawl space, where high humidity conditions may exist. If water is penetrated in the crawl space, the ventilation may not keep the floor dry and mould growth is obvious. If ventilation caps are closed, severe decay problems have been found, e.g. dry rot damage (Paajanen and Viitanen 1989, Kääriäinen et al. 1998).

In connection of the decay, also microbial contamination on the surfaces in the crawl space is typically much higher than inside the building. The level of fungal spores in the crawl space is about ten times as high as indoors. In crawl spaces, spore concentrations in a range of $10^{3}-10^{5}$ colony-forming units per gram (cfu/g) of material are common. The levels have usually been highest on wood-based boards and on timber (Hyvärinen et al. 2002). In cases of heavy fungal colonisation, airborne spore concentrations of up to $10^{3}-10^{4} \mathrm{cfu} / \mathrm{m}^{3}$ have been detected.

The slab-on-ground structure without thermal insulation below the concrete slab has been used in old buildings. This type a floor is very sensitive for water damage and microbial growth. Especially in detached houses built between 1960 and 1980, wooden beams are often supported on concrete slabs on grade. Partial decay or insect damage is often found in the lower sill plate of exterior walls due to water penetration from the basement (Kääriäinen et al. 1998).

Decay is the more severe result of high moisture exposure of wooden structures when the materials are wet for long periods. According to laboratory studies, the growth of decay fungi and decay development can start when the ambient humidity level in the microclimate remains for several weeks above RH 95 - $100 \%$ and moisture content of pine sapwood above 25 - 30 \% (Viitanen and Ritschkoff 1991b, Morris et al 2006). According to experience, decay will develop when moisture content of wood exceeds the fibre saturation point ( $\mathrm{RH}$ above $99.9 \%$ or wood moisture content $30 \%$, but also the variation of conditions and temperature has an important effect.

\subsection{Modeling the decay development}

\subsubsection{A model for decay development in pine sapwood}

There is always a vide variation within the growth condition of different fungus species, and we need overall evaluation on the growth activity and decay development of a "typical" example fungi like typical decay fungi (e.g. Coniophora puteana or Gloeophyllum sepiarium). VTT has done comprehensive research in mould and decay growth and their numerical modelling on timber (Viitanen 1996, Viitanen et al 2003) presented a model of decay development in pine and spruce sapwood.

Later a new model was developed from the work presented in references Viitanen and Ritschkoff (1991b), Viitanen (1996), and Viitanen (1997). In these references, the decay growth of brown rot in spruce and pine sapwood is studied experimentally in different constant relative humidity and temperature conditions. In the present model, only the data of pine sapwood is considered. Based on the experimental findings presented in references, a model for variable conditions is proposed (Toratti et al 2009)). This model is a time stepping scheme. The development of decay is modelled with two consecutive processes: 


\section{a) Activation process:}

This is termed as $\alpha$ parameter, which is initially 0 and gradually grows depending on the air conditions to a limit value of 1 . This process is able to recover in favourable conditions (dry air) at a given rate (although no experimental evidence of recovery is available).

b) Mass loss process:

This occurs when the activation process has fully developed $(\alpha=1)$ otherwise it does not occur. This process is naturally irrecoverable.

These processes only occur when the temperature is $0 . .30^{\circ} \mathrm{C}$ and the relative humidity is $95 \%$ or above. Outside these condition bounds, the activation process may recover, but the mass loss process is simply stopped. The activation process is as given in Equation 2. The recovery time (i.e. $\alpha$ recovers from a value of 1 back to 0 ) is assumed to be 17520 hours ( 2 years). Recovery takes place when the conditions are outside the bounds of the decay growth.

The model can be used for evaluation the exposure condition for the eventual risk of decay to develop. For example, recorded temperatures and relative humidity are given for the Helsinki area. This climate is shown in the figure 1 for a one year period. According to the model, this climate seems to induce a low mass loss of $1.1 \%$ in 4 years (Figures 4 and 5). During the first year, no decay development will occur in untreated pine sapwood. After 3 and 4 years exposure, decay is expected to occur only to a very limited extent in the surface of unprotected pine sapwood. Under normal use conditions, the cladding is protected by paints or other coatings. The direct influence of water on the wood surface is very small, and decay development will be significantly retarded or even negligible.

Activation process $\alpha=0 . .1$

$$
\begin{aligned}
& \alpha(t)=\int_{0}^{t} d \alpha=\sum_{0}^{t}(\Delta \alpha), \text { where } \\
& \Delta \alpha=\frac{\Delta t}{t_{\text {crit }}(R H, T)} \text { or (in favorable conditions of decay) } \\
& t_{\text {crit }}(R H, T)=\left[\frac{2.3 T+0.035 R H-0.024 T \times R H}{-42.0+0.14 T+0.45 R H}\right] \times 30 \times 24 \text { [hours] }
\end{aligned}
$$

The mass loss process proceeds the activation process, when a has reached 1(Eq. 11).

Massloss process when $\alpha \geq 1$

$$
\begin{aligned}
& M L\left(t^{\prime}\right)=\int_{\text {tat } \alpha=1}^{t^{\prime}} \frac{M L(R H, T)}{d t} d t=\sum_{\text {tat } \alpha=1}^{t^{\prime}}\left(\frac{M L(R H, T)}{d t} \times \Delta t\right) \\
& \frac{M L(R H, T)}{d t}=-5.96 \times 10^{-2}+1.96 \times 10^{-4} T+6.25 \times 10^{-4} R H[\% / \text { hour }]
\end{aligned}
$$

For advanced decay to develop, a significantly longer period is needed, and after a 10 years period, severe decay in unprotected and uncovered pine sapwood can be expected in the Helsinki area. The design of details has a strongly marked effect on the durability and 
service life of wood structure. If there is a detail collecting the water, the moisture conditions are suitable for long time for decay to develop. If the structure and details are well planned so that there is no water sink and the structure can be dried after occasionally wetting, the conditions for decay development will not be reached, and there are actually no limits for the service life of wood.

\subsubsection{Evaluation of decay risk in different part of Europe using decay model}

The empirical wood decay model was run using the ERA-40 data for air temperature, humidity and precipitation at 6 hour intervals (Viitanen et al 2010b). ERA-40 is a massive data archive produced by the European Centre of Medium-Range Weather Forecasts (ECMWF). The reanalysis involves a comprehensive use of a wide range of observational systems including, of course, the basic synoptic surface weather measurements. The ERA-40 domain covers all of Europe and has a grid spacing of approximately $270 \mathrm{~km}$. The nature of the data and the reanalysis methods of ERA-40 are described in detail in Uppala et al. [2005]. The evaluation of decay development in the model is based on the mass loss caused by the decay fungus. Within specified limitations, the mass loss is an applicable variable for evaluating the decay development in wood. The decay development model will give a general assumption of the effect of humidity, temperature and exposure time on the start and progress of the decay.

The resulting modelled mass loss in 1961-1970 at the calculation points of the ERA-40 grid were analyzed by a chart production software producing a maps of wood decay in Europe (Figure 7). First a map on decay risk protected from rain and then a map on decay risk of pine sapwood exposed to rain. A modification of the weather data was made so that the humidity of air was set to $100 \%$ during precipitation (at non-freezing temperatures) as this is thought to result in a full saturation in the wood surface.

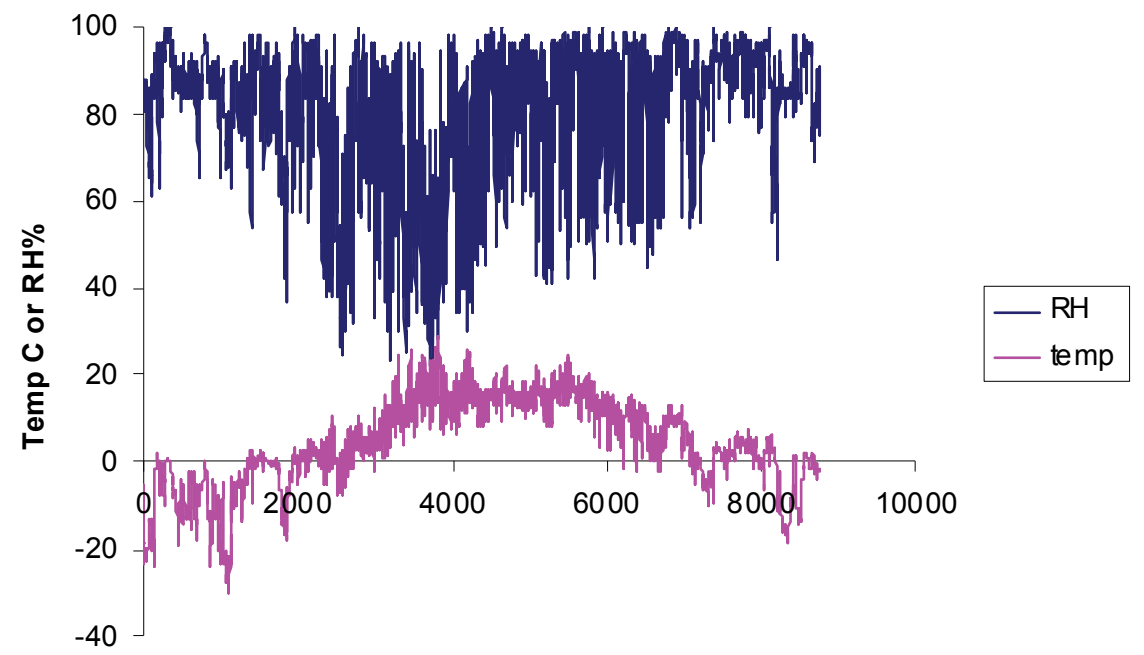

Time [h]

Fig. 5. Measured climate data (Helsinki) used in the decay model for one year (Viitanen et al 2010b) 


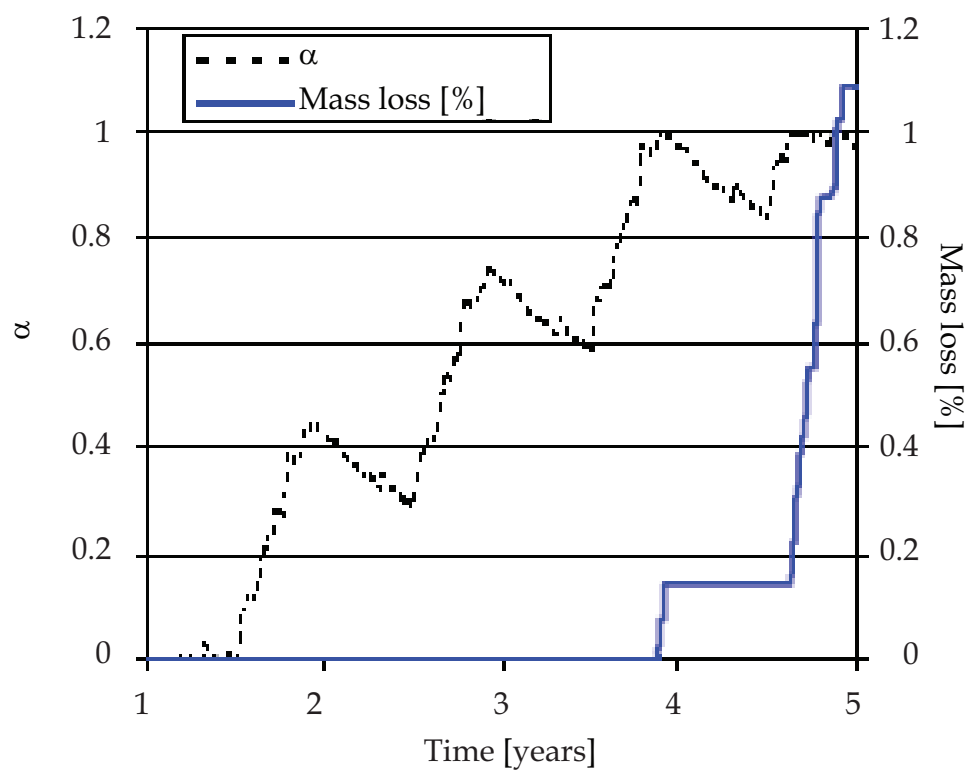

Fig. 6. No activation of growth or decay development during the first and second years, an activation of decay process after 4 years exposure may be expected (Viitanen et al 2010b)
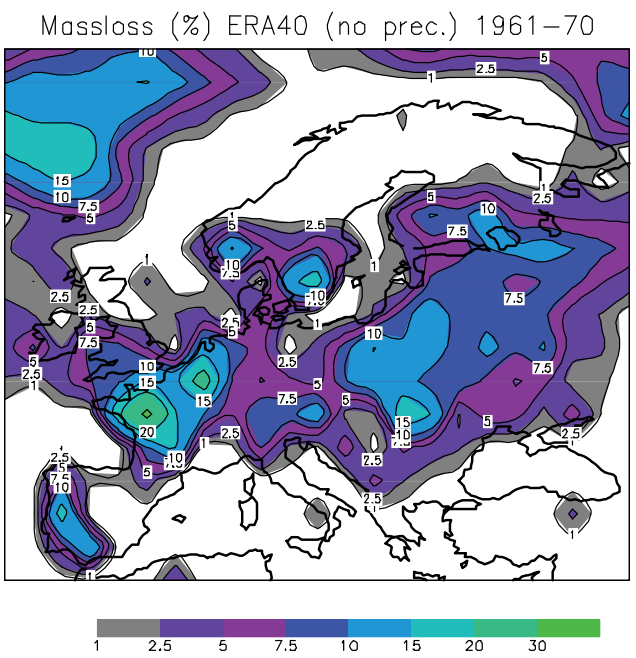
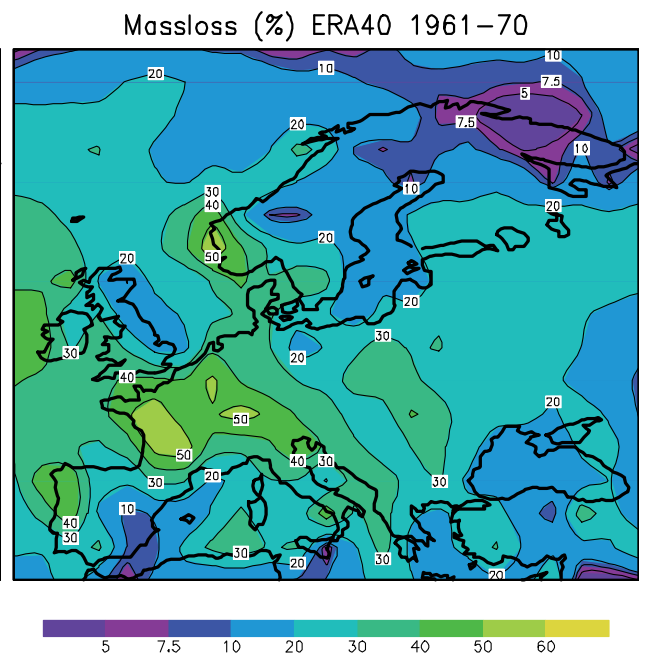

Fig. 7. a) Modelled mass loss (in \%) of small pieces of pine wood that are protected from the rain or b) exposed to rain in 10 years in Europe (from [Viitanen et al. 2010b, 2011b)

The risk of decay activity in different part of Europe can be evaluated on the map. If we evaluate the decay activity rate in Helsinki to be 1, then the decay risk in north-western part of Portugal and in West Ireland is 2 times and in Atlantic part of France and Belgium it will 
be between 2 and 2.5 times higher than that in Helsinki. In North Scandinavia it would be between 0.5 and 0.25 , which will point out, the effect if climate on risk of decay development in outdoor structure varied vide within Europe. These coefficients can be used as one step to evaluate the effect of macroclimate conditions on service life of cladding and decking.

Another way to evaluate the macroclimate conditions is presented by Thelandersson et al (2011) using Meteonorm climate data. By calculating the daily dose and accumulating the dose for one year a measure of the risk of decay is obtained. This is made for several sites, and the result in terms of dosedays can be compared between the different sites. To be able to compare different sites, the dose was transferred to a relative dose by dividing it by the dose for the "base-station" Helsinki. Due to the variation of climate across Europe, relative doses between 0.6 (northern Scandinavia) and 2.1 (Atlantic coast in Southern Europe) were obtained.

\section{Conclusion}

There are several factors involved with the bio-deterioration of materials and buildings, and mathematic modelling that may help us to understand the complicated interaction of many factors. The presented numerical mould growth and decay development models are based on experimental results from several research projects. It is suitable for post-processing temperature and humidity data from any numerical simulation of hygrothermal conditions in building constructions. However, it must be kept in mind when performing the assessment that there is a great uncertainty coupled to this kind of analysis: the variation of the material sensitivities is high, estimation of a product sensitivity class is difficult without testing, the surface treatments may enhance or reduce growth potential, different mould species have different requirements for growth and the evaluation of the actual conditions in the critical material layers may include uncertainties. The best way to use the predicted mould growth and decay development as an assessment tool is to compare different solutions with each others: The solution with the lowest risk for the mould growth or decay development would most probably also have least other moisture related problems

\section{Acknowledgment}

This chapter is based on several research performed at VTT and other research institutes and universities.

\section{References}

Adan, O.C.G. 1994. On the fungal defacement of interior finishes. Eindhoven University of Technology. Thesis. Eindhoven, pp. 83-185.

Ayerst, G. 1969. The effects of moisture and temperature on growth and spore germination in some fungi. J. Stored Prod. Res. 5:127-141.

Clarke, J.A. Johnstone, C.M. Kelly, N.J. Mclean, R.C. Anderson, J.A., Rowan N.J. and Smith, J.E. 1998. A technique for prediction of the conditions leading to mould growth in buildings. Building and Environment 34 pp 515-521.

Grant, C., Hunter, C.A., Flannigan, B. and Bravery, A.F. 1989. The moisture requirements of moulds isolated from domestic dwellings. Internat. Biodet. 25:259-284. 
Hens, H.L.S.C. 1999. Fungal defacement in buildings: A performance related approach. International Journal of Heating, Ventilation, Air-Conditioning and Refrigerating Research, Vol. 5, H3, pp. 256-280

Hukka, A. and Viitanen, H. 1999. A mathematical model of mould growth on wooden material. Wood Science and Technology 33(6):475-485.

Hyvärinen, A., Meklin, T., Vepsäläinen, A. and Nevalainen, A. 2002. Fungi and actinobacterai in moisture-damaged building materials - concentrations and diversity, International Biodeterioration and biodegradation 49:27-37.

Kääriäinen, H., Rantamäki, J. and Tulla, K. Moisture Performance of Wooden Buildings. Feedback Knowledge of Actual Buildings. 1998. Espoo: Technical Research Centre of Finland. 85 p. (VTT Research Notes 1923). 63 p. + app. 14 p. (in Finnish).

Ojanen, T; Viitanen, H; Peuhkuri, R; Lähdesmäki, K; Vinha, J; Salminen, K. 2010. Mould growth modeling of building structures using sensitivity classes of materials. Thermal Performance of the Exterior Envelopes of Whole Buildings XI International Conference; (Buildingx XI), December 5-9, 2010, Clearwater Beach, Florida. Proceedings of Thermal Performance of the Exterior Envelopes of Whole Buildings XI International Conference (CD). DOE, BETEC, ASHRAE, Oak Ridge National Laboratory (ORNL) (2010), 10 p.

Paajanen, L. and Viitanen, H. 1989. Decay fungi in Finnish houses on the basis of inspected samples from 1978 to 1988. The International Research Group on Wood Preservation, IRG Doc. No: IRG/WP/1401. 4 p.

Sedlbauer, K. 2001. Prediction of mould fungus formation on the surface of/and inside building components. University of Stuttgart, Fraunhofer Institute for building Physics, Doctoral thesis. Stuttgart. Germany.

Sedlbauer K. and Krus, M. 2003. A new model for mould prediction and its application in practice. In Research in Building Physics. Ed. by Carmeliet, J. et al. Proc. of 2nd International conference on Building Physics

Smith, S.L. and Hill, S.T. 1982. Influence of temperature and water activity on germination and growth of Aspergillus restrictus and Aspergillus versicolor. Transactions of the British Mycological Society, Vol. 79, H 3, pp. 558-560.

Thelandersson, S.; Isaksson, T., Suttie, E., Früwald, E., Toratti, T., Grüell, G., Viitanen, H. and Jermer, J. 2011. Quantitative design guideline for wood outdoors above ground applications. Proceedings IRG Annual Meeting 2011, IRG/WP 11-20465

Toratti, T; Viitanen, H; Peuhkuri, R; Makkonen, L; Ojanen, T; Jämsä, S..2009. Modelling of durability of wooden structures. 4th International Building Physics conference IBPC 2009, Istanbul, Turkey, 15-18 June 2009. Istanbul Technical University. Istanbul, Turkey (2009), 127-134

Uppala, S.M., Kållberg, P.W., Simmons, A.J., Andrae, U., da Costa Bechtold, V., Fiorino, M., Gibson, J.K., Haseler, J., Hernandez, A., Kelly, G.A., Li, X., Onogi, K., Saarinen, S., Sokka, N., Allan, R.P., Andersson, E., Arpe, K., Balmaseda, M.A., Beljaars, A.C.M., van de Berg, L., Bidlot, J., Bormann, N., Caires, S., Chevallier, F., Dethof, A., Dragosavac, M., Fisher, M., Fuentes, M., Hagemann, S., Hólm, E., Hoskins, B.J., Isaksen, L., Janssen, P.A.E.M., Jenne, R., McNally, A.P., Mahfouf, J.-F., Morcrette, J.J., Rayner, N.A., Saunders, R.W., Simon, P., Sterl, A., Trenberth, K.E., Untch, A., Vasiljevic, D., Viterbo, P., and Woollen, J. 2005: The ERA-40 re-analysis. Quarterly Journal. of the Royal Meteoroogical Society, 131, 2961-3012. 
Viitanen, H. 1996. Factors affecting the development of mould and brown rot decay in wooden material and wooden structures. Effect of humidity, temperature and exposure time. Doctoral Thesis, Uppsala, The Swedish University of Agricultural Sciences, Department of Forest Products.

Viitanen, H. 1997. Critical time of different humidity and temperature conditions for the development of brown rot decay in pine and spruce. Holzforschung 51 (2): 99-106

Viitanen, H. 2001a. Biodegradation of cultural heritage, state of the art, Finland. ARIADNE Workshop: "Biodegradation of cultural heritage". Prague, December 10-15, 2001. Academy of Sciences of the Czech Republic, ITAM - ARCCHIP. 7 p.

Viitanen, H. and Ritschkoff, A. 1991a. Mould growth in pine and spruce sapwood in relation to air humidity and temperature. Uppsala. The Swedish University of Agricultural Scienses, Department of Forest Products. Report no 221. 40 p. + app. 9 p.

Viitanen, H. \& Ritschkoff, A. 1991b. Brown rot decay in wooden constructions. Effect of temperature, humidity and moisture. Uppsala. Swedish University of Agricultural Scienses, Department of Forest Products. Report no 222. $55 \mathrm{p}+$ appendix $2 \mathrm{p}$

Viitanen, H. and Salonvaara, M. 2001. Failure criteria. In Trechsel, E (Ed.). Moisture analysis and condensation control in building envelopes. American Society for Testing and Materials ASTM MNL40, pp. 66-80.

Viitanen, H., Hanhijärvi, A., Hukka, A. and Koskela, K. 2000. Modelling mould growth and decay damages Healthy Buildings. Espoo, 6 - 10 August 2000. Vol. 3. FISIAQ, 2000, pp. 341-346.

Viitanen, H., Ritschkoff, A-C., Ojanen, T. and Salonvaara, M. 2003. Moisture conditions and biodeterioration risk of building materials and structure. Proceedings of the 2nd International Symposium ILCDES 2003. Integrated Lifetime Engineering of Buildings and Civil Infrastructures, Kuopio, 1-3 Dec. 2003 RIL, VTT, RILEM, IABSE, ECCE, ASCE. Espoo (2003), pp. 151 - 156.

Viitanen, H; Vinha, J; Salminen K; Ojanen, T; Peuhkuri, R. Paajanen, L; Lähdesmäki, K. 2010a. Moisture and bio-deterioration risk of building materials and structures. Journal of Building Physics. 33 (3) 201-224.

Viitanen, H, Toratti, T. Makkonen, L. Peuhkuri, R. Ojanen, T. Ruokoloainen, L. and Räisänen, J. 2010b. Towards modelling of decay risk of wooden materials. Eur. J. Wood Prod. 68: 303-313.

Viitanen, H, Ojanen, T, Peuhkuri, R.; Vinha, J, Lähesmäki, K., Salminen, K. 2011 a. Mould growth modelling to evaluate durability of materials. $12^{\text {th }}$ International Conference on Durability of Building Materials and Components. Conference Proceedings, Vol 1. $409-416$.

Viitanen, H. Toratti, T, Makkonen, L. 2011b. Development of service life model for wooden structures. . 12 $2^{\text {th }}$ International Conference on Durability of Building Materials and Components. Conference Proceedings, Vol 1. pp 495 - 502. 


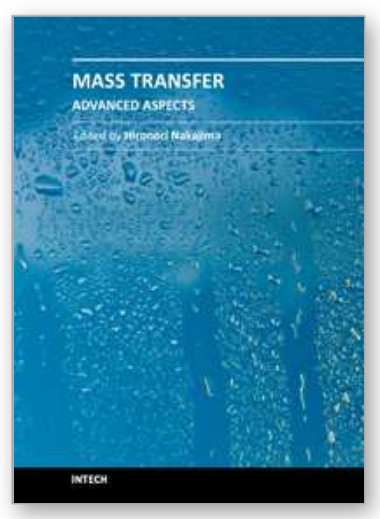

\author{
Mass Transfer - Advanced Aspects \\ Edited by Dr. Hironori Nakajima
}

ISBN 978-953-307-636-2

Hard cover, 824 pages

Publisher InTech

Published online 07, July, 2011

Published in print edition July, 2011

Our knowledge of mass transfer processes has been extended and applied to various fields of science and engineering including industrial and manufacturing processes in recent years. Since mass transfer is a primordial phenomenon, it plays a key role in the scientific researches and fields of mechanical, energy, environmental, materials, bio, and chemical engineering. In this book, energetic authors provide present advances in scientific findings and technologies, and develop new theoretical models concerning mass transfer. This book brings valuable references for researchers and engineers working in the variety of mass transfer sciences and related fields. Since the constitutive topics cover the advances in broad research areas, the topics will be mutually stimulus and informative to the researchers and engineers in different areas.

\title{
How to reference
}

In order to correctly reference this scholarly work, feel free to copy and paste the following:

Hannu Viitanen (2011). Moisture and Bio-Deterioration Risk of Building Materials and Structures, Mass Transfer - Advanced Aspects, Dr. Hironori Nakajima (Ed.), ISBN: 978-953-307-636-2, InTech, Available from: http://www.intechopen.com/books/mass-transfer-advanced-aspects/moisture-and-bio-deterioration-risk-ofbuilding-materials-and-structures

\section{INTECH}

open science | open minds

\section{InTech Europe}

University Campus STeP Ri

Slavka Krautzeka 83/A

51000 Rijeka, Croatia

Phone: +385 (51) 770447

Fax: +385 (51) 686166

www.intechopen.com

\section{InTech China}

Unit 405, Office Block, Hotel Equatorial Shanghai

No.65, Yan An Road (West), Shanghai, 200040, China

中国上海市延安西路65号上海国际贵都大饭店办公楼 405 单元

Phone: +86-21-62489820

Fax: +86-21-62489821 
(C) 2011 The Author(s). Licensee IntechOpen. This is an open access article distributed under the terms of the Creative Commons Attribution 3.0 License, which permits unrestricted use, distribution, and reproduction in any medium, provided the original work is properly cited. 